\title{
Interannual variability of tropical cyclone activity along the Pacific coast of North America
}

\author{
D. S. GUTZLER \\ Department of Earth and Planetary Sciences, University of New Mexico, \\ Albuquerque, New Mexico \\ K. M. WOOD and E. A. RITCHIE \\ Department of Atmospheric Sciences, The University of Arizona, Tucson, Arizona \\ Corresponding author: K. M. Wood; e-mail: wood@atmo.arizona.edu \\ A. V. DOUGLAS and M. D. LEWIS \\ Department of Atmospheric Sciences, Creighton University, Omaha, Nebraska
}

Received December 1, 2011; accepted September 14, 2012

\begin{abstract}
RESUMEN
Se describe la variabilidad interanual de ciclones tropicales cercanos a la costa en el Pacífico nororiental, utilizando para ello un conjunto de datos elaborado con reportes oceánicos y atmosféricos de EUA y México correspondientes al periodo 1951-2006. Los ciclones cercanos a la costa se enumeran de forma mensual, lo que permite distinguir la variabilidad interanual en distintas fases de la temporada de ciclones de mayo a noviembre. De acuerdo con estos datos, el número de ciclones tropicales que impactan la costa del Pacífico de mayo a julio (los primeros meses de la temporada de ciclones tropicales) en años correspondientes a La Niña, cuando las temperaturas marinas superficiales en el Pacífico ecuatorial son anormalmente frías, es mayor que en años correspondientes a El Niño. La diferencia en la cantidad de ciclones tropicales de inicio de temporada entre años de La Niña y El Niño fue especialmente notable a mediados del siglo XX, cuando se registró un incremento de las temperaturas ecuatoriales bajas, de acuerdo con un índice de la oscilación decenal del Pacífico. Los mapas combinados de años con conteos bajos y altos de ciclones tropicales cercanos a la costa muestran que las anomalías de la circulación atmosférica vinculadas con bajas temperaturas marinas superficiales en el Pacífico ecuatorial oriental, son consistentes con la trayectoria dominante de los ciclones tropicales hacia el noreste con dirección a la costa occidental de México.
\end{abstract}

\begin{abstract}
The interannual variability of near-coastal eastern North Pacific tropical cyclones is described using a data set of cyclone tracks constructed from U.S. and Mexican oceanic and atmospheric reports for the period 1951-2006. Near-coastal cyclone counts are enumerated monthly, allowing us to distinguish interannual variability during different phases of the May-November tropical cyclone season. In these data more tropical cyclones affect the Pacific coast in May-July, the early months of the tropical cyclone season, during La Niña years, when equatorial Pacific sea surface temperatures are anomalously cool, than during El Niño years. The difference in early season cyclone counts between La Niña and El Niño years was particularly
\end{abstract}


pronounced during the mid-twentieth century epoch when cool equatorial temperatures were enhanced as described by an index of the Pacific Decadal Oscillation. Composite maps from years with high and low near-coastal cyclone counts show that the atmospheric circulation anomalies associated with cool sea surface temperatures in the eastern equatorial Pacific are consistent with preferential steering of tropical cyclones northeastward toward the west coast of Mexico.

Keywords: tropical cyclones, ENSO, eastern North Pacific.

\section{Introduction}

Eastern North Pacific tropical cyclones are a significant factor in the summer precipitation regime across Central America and southwestern North America. The necessary climatic ingredients for such storms - warm ocean temperatures, modest vertical wind shear, and incipient disturbances to facilitate cyclogenesis - are generally present in the eastern North Pacific during the warm season (Serra, 1971; Whitney and Hobgood, 1997; Englehart and Douglas, 2001; Magaña, 2004).

The genesis and evolution of individual tropical cyclones, like any transient dynamical feature in the atmosphere, are inherently unpredictable at an interannual time scale. However, probabilistic seasonal prediction schemes for the total number of Atlantic tropical cyclones have gained increasing skill in recent years (e.g., Klotzbach and Gray, 2004; Klotzbach, 2008) based on antecedent or slowly varying factors such as the El Niño-Southern Oscillation (ENSO) cycle. The skill of such schemes demonstrates that slowly varying, predictable climatic boundary conditions may yield seasonal prediction skill for total numbers of tropical cyclones over large regions.

Establishing analogous seasonal predictability in the summertime climate of North America (for tropical cyclones or continental precipitation) has proven elusive, however. Across southwestern North America, various studies have described weak and sometimes contradictory summertime ENSO-related climate signals (Gutzler and Preston, 1997; Higgins et al., 1999; Castro et al., 2001; $\mathrm{Hu}$ and Feng, 2001; Caso et al., 2007). Multidecadal fluctuations, such as the Pacific Decadal Oscillation (PDO), seem to modulate both the structure of interannual variability of precipitation associated with patterns such as ENSO (Mantua et al., 1997; Gershunov and Barnett, 1998; McCabe and Dettinger, 1999; Englehart and Douglas, 2001) as well as seasonal predictability (Gutzler, 2000; Hu and Feng, 2001; Lo and Clark, 2002).

A general inverse relationship has been noted between hurricane activity in the North Atlantic and eastern North Pacific basins (Gray, 1984; Lander and Guard, 1998; Larson et al., 2005). This inverse relationship is explained in part by the different effects of ENSO anomalies on the tropospheric zonal wind shear in the North Atlantic and eastern North Pacific basins. The deep zonal circulation associated with warm sea surface temperature (SST) anomalies in the equatorial Pacific (El Niño) acts to increase zonal wind shear in the North Atlantic (thus suppressing the tendency for North Atlantic tropical cyclone development) and decrease zonal wind shear in the eastern North Pacific (thus enhancing the tendency for eastern North Pacific tropical cyclone development).

However, the ENSO-related signal in eastern North Pacific tropical cyclone activity seems to be statistically weaker than in the North Atlantic (Gray, 1984; Magaña et al., 2003; Frank and Young, 2007), and the robustness of the relationship between ENSO and near-coastal tropical cyclone activity in the eastern North Pacific has been questioned (Whitney and Hobgood, 1997; Ralph and Gough, 2009). Consideration of decadal and longitudinal variability in the tropical Pacific may improve the ENSO-cyclone activity relationship. Reyes and Mejía-Trejo (1991) confirmed the 
negative correlation between eastern North Pacific SST and tropical cyclone activity only during a relatively cold period from 1967-1979, but the correlation they found changed sign during the warmer 1980s so that positive SST anomalies corresponded to enhanced eastern North Pacific tropical cyclone activity. Zhao and Chu (2006) indicated other possible dates of decadal shifts (1982, 1999) using a change point analysis.

Longitudinal variability also affects the ENSO-tropical cyclone relationship in the eastern North Pacific. Collins and Mason (2000) showed that eastern North Pacific tropical cyclone statistics were different in the far eastern North Pacific (east of $116^{\circ} \mathrm{W}$ ) compared with the region west of $116^{\circ} \mathrm{W}$. Other analyses also indicate that the seasonal track distribution of tropical cyclones responds to longitudinal variations in ocean temperature anomalies, even if the total seasonal number of storms might not (Irwin and Davis, 1999; Kim et al., 2011).

The U.S. National Weather Service (NWS) and Servicio Meteorólogico Nacional de México (SMN) now issue operational seasonal forecasts of eastern North Pacific hurricane activity, with the total seasonal cyclone count as a common predictand. The NWS specifically notes that no prediction is attempted for numbers of landfalling tropical storms. The SMN seasonal outlook is based on an analog scheme in which oceanic and atmospheric circulation anomalies for the current year are matched with similar previous years.

The present analysis documents the interannual variability of near-coastal eastern North Pacific tropical cyclones, examines the modulation of total seasonal cyclone counts by interannual and decadal modes of oceanic variability, and relates the results to interannual variability of total seasonal precipitation in northwestern Mexico. We extend previous results principally by separately considering early season and late season cyclones.

Wu and Chu (2007) noted that the primary difference between synoptic conditions in 1977 (a quiet year for eastern North Pacific cyclones) and 1992 (an active year) occurred in the early months of the tropical cyclone season. This analysis confirms their result and indicates more generally that the relationship between ENSO and near-coastal eastern North Pacific tropical cyclones is strongest in the first few months of the storm season. These results indicate that, in addition to decadal and longitudinal variability, sub-seasonal considerations are important for understanding and predicting the continental effects of eastern North Pacific cyclone activity.

\section{Data and methodology}

A data set of eastern North Pacific near-coastal tropical cyclones developed by Lewis (2003) is used for this study. Lewis (2003) enumerated the number of tropical cyclones in the eastern North Pacific basin along the west coast of North America, including disturbances of depression strength $(<17 \mathrm{~m} / \mathrm{s})$ for each month during the period 1921-2002. His census was based on examination of individual tropical cyclone tracks from a variety of U.S. and Mexican data sources, acknowledging that pre-satellite era tracks are subject to considerable uncertainty. The present study incorporates cyclone counts starting in 1951, when the Lewis (2003) data rely principally on storm tracks from the NWS and Colorado State University, validated by surface oceanic in situ data (International Comprehensive Ocean-Atmosphere Data Set, ICOADS) and weather observations from the SMN. With these additional sources of data Lewis (2003) significantly augmented eastern North Pacific tropical storm counts prior to 1950. For the period of time we are considering, however, there should be little difference between the data we are using and other sources of track data. 
The number of tropical cyclones affecting continental locations ("near-coastal cyclones") was determined by counting only those tropical cyclones for which the low pressure center moved within $550 \mathrm{~km}\left(5^{\circ}\right)$ of the west coast of North America. This distance was selected based on previous research (Englehart and Douglas, 2001) showing that tropical cyclones within this distance from the coast were likely to generate observable precipitation at coastal stations.

We have updated data from Lewis (2003) through 2006 using the best track archive from the National Oceanic and Atmospheric Administration (NOAA) National Hurricane Center (NHC; Davis et al., 1984) to provide near-coastal cyclone counts. In total, the principal data set for this analysis is the number of near-coastal cyclones each month during the May-November tropical cyclone season for the 56 years from 1951 to 2006.

Monthly near-coastal cyclone counts are compared with the monthly Niño3 ENSO index obtained from the NOAA Climate Prediction Center (CPC). Niño3 is the monthly mean SST value averaged between $5^{\circ} \mathrm{S}-5^{\circ} \mathrm{N}$ latitude and $150-90^{\circ} \mathrm{W}$ longitude. The Niño3 index was chosen to represent ENSO variability for this study, rather than other ENSO indices based on regions farther west, because it represents equatorial Pacific SST variability directly south of the Mexican coast affected by tropical cyclones. Previous analyses of ENSO and rainfall variability (e.g., Gershunov and Barnett, 1998; Englehart and Douglas, 2001; Gutzler et al., 2002) have found a distinct change in statistics of interannual variability before and after 1977, when Pacific Ocean SSTs and the atmospheric circulation shifted in association with the PDO (Graham, 1994; Mantua et al., 1997). We therefore examine relationships between SST and tropical cyclone counts for separate periods before and after 1977.

To interpret the statistical modulation of near-coastal cyclone counts in terms of regional atmospheric circulation, composite analyses of atmospheric fields were derived from the National Centers for Environmental Prediction/National Center for Atmospheric Research (NCEP/NCAR) reanalysis data set (Kalnay et al., 1996). Use of the online compositing tool maintained by the NOAA Earth System Research Laboratory (http://www.esrl.noaa.gov/psd/cgi-bin/data/composites/printpage. pl) facilitated this analysis.

We next consider the interannual covariability of cyclone counts and continental rainfall variability. Interannual variability of tropical cyclones may have different causes than interannual monsoon fluctuations, so attempts to understand, and predict, seasonal anomalies in summer rainfall must distinguish precipitation generated by "monsoonal" processes from precipitation produced by tropical cyclones. The fraction of total summertime rainfall along the Mexican coast attributable to near-coastal cyclones ranges from 10-20\% on average (Jáuregui, 2003; Larson et al., 2005) to as much as $60 \%$ in some regions (Englehart and Douglas, 2001) or more during particular years.

To complement and extend previous results, we examine the covariability of seasonal nearcoastal cyclone counts with the seasonal rainfall in regions defined by Gutzler (2004). These regional rainfall anomalies were derived from varimax-rotated empirical orthogonal function (EOF) analysis of warm season interannual variability across southwestern North America. The NOAA CPC gridded daily precipitation analysis (Higgins et al., 1999) was used as the basis for the EOF calculations. Gutzler (2004) carried out separate analyses of interannual variability for the early part of the warm season (mid-May through June) and the core of the monsoon season in northwestern Mexico (July through mid-September). This analysis generated annual time series of precipitation for "early monsoon" and "late monsoon" seasons averaged over subregions exhibiting spatially coherent seasonal rainfall totals. 


\section{Interannual variability of near-coastal cyclones, ENSO, and continental precipitation}

\subsection{Climatology and interannual variability}

The seven-month tropical cyclone season begins in May each year, with a broad average seasonal maximum of near-coastal cyclones from July-September followed by a rapid decrease. The shape of the seasonal cycle of near-coastal cyclone counts in the 1951-2006 data record (Fig. 1) is consistent with results found from other periods and data sources (Serra, 1971; Jáuregui, 2003; Lewis, 2003). The annual average count in this data set is 8.8, ranging from 4 to 13 during the period of record (Fig. 2). A slight annual average decrease (from 8.9 to 8.6 tropical cyclones per year, not statistically significant) is associated with the 1977 PDO shift.

Near-coastal cyclone counts are more variable from year to year during the early months of the season. The annual time series of tropical cyclone counts in Fig. 2 shows the annual total as well as sub-seasons divided into an early phase (May-July, MJJ) and a late phase (August-November, ASON). The standard deviation of annual tropical cyclone counts is considerably larger in the early phase (1.5/year in MJJ, compared to 1.3/year in ASON), despite the smaller average number of near-coastal cyclones in MJJ compared to ASON. There is no significant lag correlation between the annual number of near-coastal cyclones in MJJ and ASON $(r=0.1$ for the 56-year period of record), so the tropical cyclone count in the early phase provides no statistical predictability of the tropical cyclone count in the later months during the peak of the tropical cyclone season (Fig. 1).

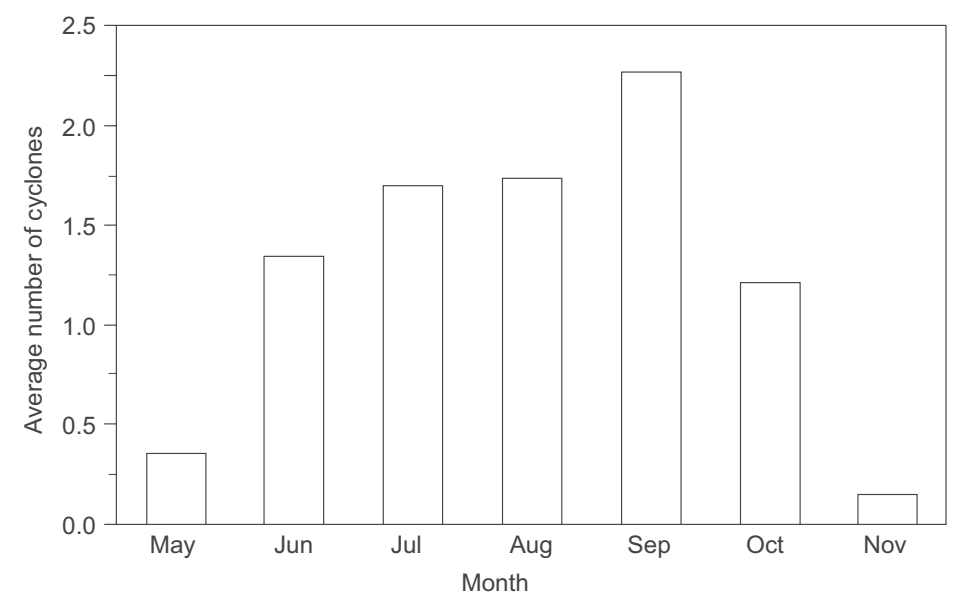

Fig. 1. Average number of near-coastal cyclones per month from May to November during the period 1951-2006.

Interannual variability of near-coastal cyclone counts is significantly negatively correlated with Niño3 SST. Over the entire period of record the correlation between the seasonal tropical cyclone count and May-November Niño3 SST is -0.32 (statistically significant at the $5 \%$ level assuming one degree of freedom per year) with a much higher correlation in the pre-1977 period than from 1977-2006 (Fig. 3a).

These statistics are reproduced based on MJJ near-coastal cyclone counts and Niño3 SST in Fig. 3b, showing that most of the May-November relationship to seasonal Niño3 SST comes from the early part of the season. As is the case for the entire storm season, the Niño3-cyclone count 


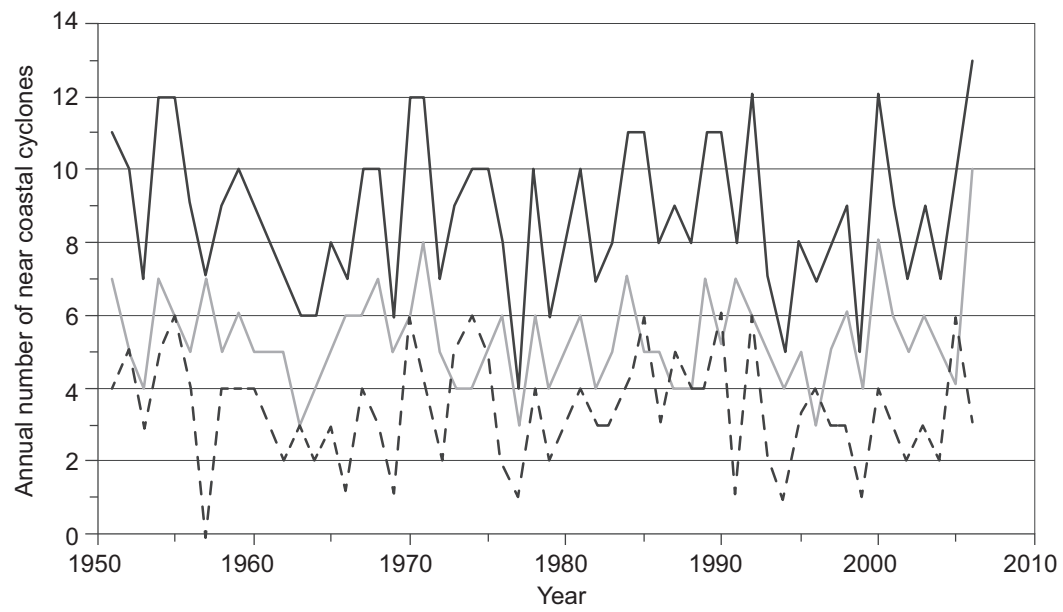

Fig. 2. Time series of annual near-coastal cyclone counts along the Pacific coast of North America, divided into May-November (solid black; mean = 8.8), MJJ (dashed; mean = 3.4), and ASON (solid grey; mean = 5.4) time periods. The interannual variability of MJJ storm counts is greater than that of ASON storm counts despite the larger average number of storms during ASON.

relationship is negative and significant for the pre-1977 decades $(r=-0.61)$ but insignificant in recent decades $(r=-0.13)$. Correlations between ASON Niño3 SST and ASON cyclone counts are insignificant over the entire period of record, a result not sensitive to PDO phase (Fig. 3c).

This shows that neither ENSO phase nor early season tropical cyclone count provides statistical predictability of the late summer-autumn (peak season) tendency for near-coastal cyclones in this data set. However, the ENSO cycle is statistically related to near-coastal cyclone counts in the early months of the storm season, when interannual variability is larger, as opposed to counts during the later, peak months of the storm season.

\subsection{Comparison with rainfall}

Interannual fluctuations of tropical cyclone counts were correlated with precipitation anomalies in each of the coherent regions of continental rainfall identified by Gutzler (2004) for both the early season (mid-May through June) and the late season (July through mid-September) identified in that paper. For comparison, these two halves of the warm season were compared with May-June (MJ) and July-September (JAS) near-coastal cyclone counts. The strongest relationship in this correlation analysis involved rainfall in a region of west-central Mexico that includes the states of Nayarit, Jalisco, and southern Sinaloa. This region was depicted in separate EOF analyses by Gutzler (2004) as mode 1 in the early season and mode 2 in the late season (Fig. 4).

In the early season, the linear correlation coefficient between mode 1 rainfall and MJ cyclone count was about 0.45 for the entire period of record as well as for either pre- or post-1977 epochs. Each of the three years with no tropical cyclones in May or June corresponds to rainfall well below average in the mode 1 region. At the other extreme, eight of the nine MJ seasons with three tropical cyclones correspond to above average rainfall in the mode 1 region. However, one or two tropical cyclones occurred during May and June in most years, and these years exhibited 

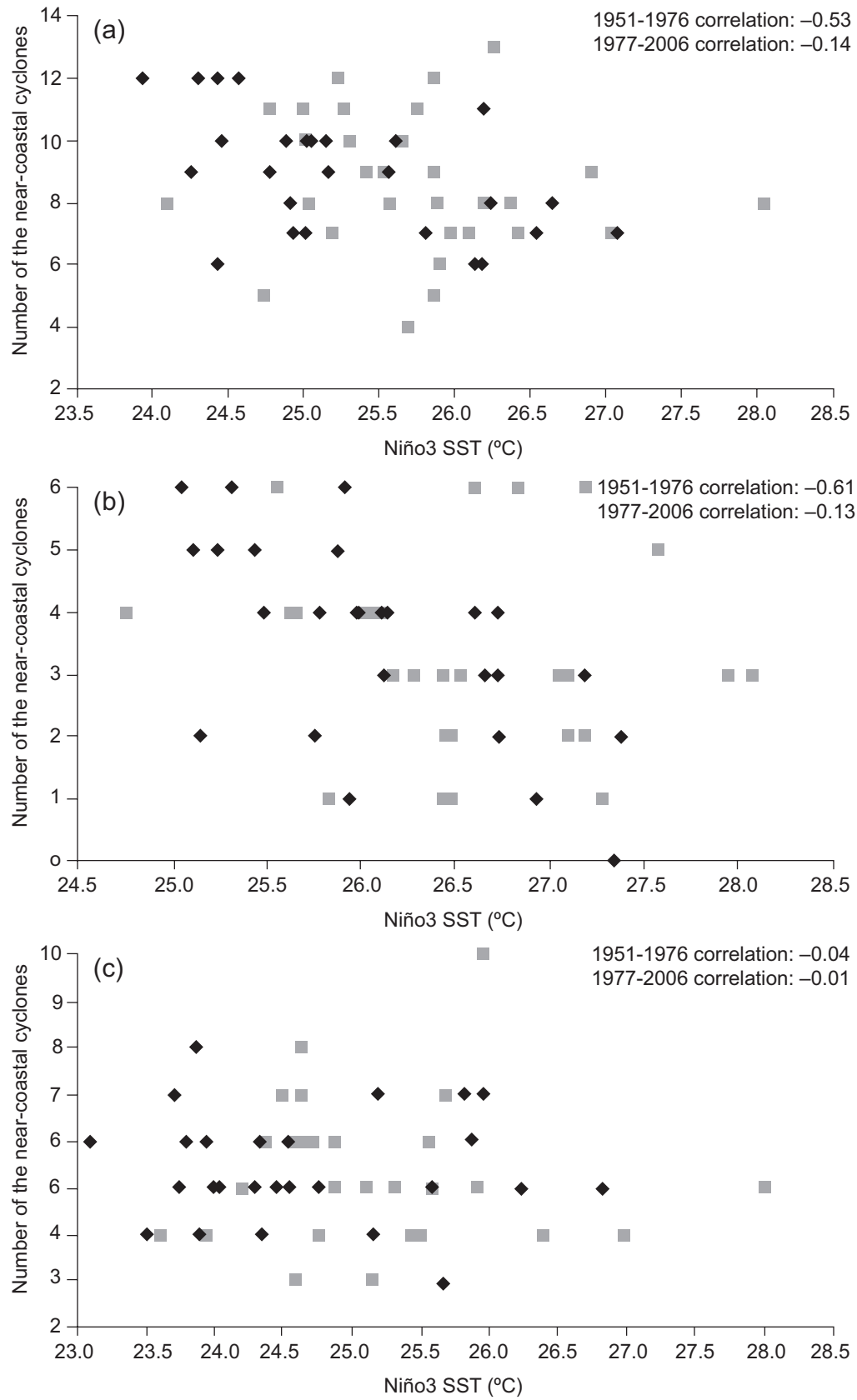

Fig. 3. Scatter plots of seasonal counts of near-coastal cyclones vs. seasonal average Niño3 SST for (a) May-November, (b) MJJ, and (c) ASON. Black diamonds denote data from 1951-1976, and grey squares denote data from 1977-2006.

little correspondence between tropical cyclone counts and rainfall anomalies across west-central Mexico, including several years with less early season rainfall than any of the three years with no near-coastal cyclones in May or June. 

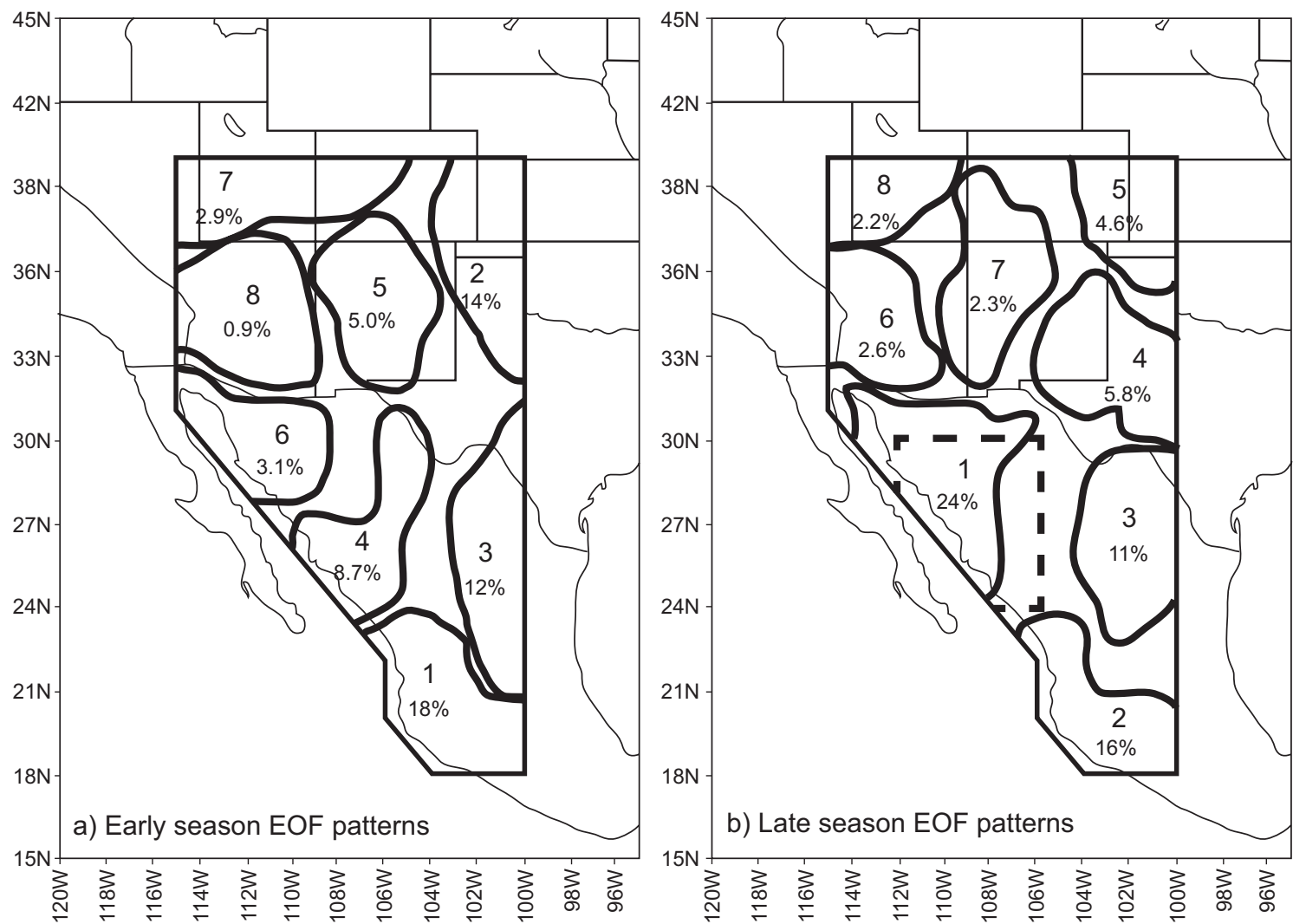

Fig. 4. Spatial patterns of interannual precipitation anomalies yielded by varimax-rotated principal component analysis of (a) early- (15 May-3 Jul) and (b) late- (5 Jul-15 Sep) season averages. The patterns are numbered $1-8$, ordered by the percentage of domain-wide interannual variance accounted for by each pattern. The core monsoon index region is delineated by a heavy dashed line. Early season mode 1 and late season mode 2 are the most correlated with near-coastal TC counts (from Gutzler, 2004).

A similar positive linear correlation (0.44) exists between JAS cyclone counts and the late season rainfall of mode 2, corresponding to nearly the same region as mode 1 of the early season. Much of the correlation is associated with high seasonal cyclone counts and positive rainfall anomalies: five of six years with eight or nine near-coastal cyclones exhibited above average rainfall, and six of the seven highest rainfall years were years with five or more cyclones in JAS.

\section{Environmental differences between years of many and few near-coastal cyclones}

Interannual variability statistics indicate that ENSO extremes are associated with years of many or few near-coastal cyclones in the boreal spring and early summer at the beginning of the tropical cyclone season. Reanalysis fields (Kalnay et al., 1996, as described in section 2) were averaged for the seven years with the most near-coastal cyclones in MJJ (1955, 1970, 1974, 1985, 1990, 1992, and 2005), and corresponding seven-year averages were created for the years with the fewest near-coastal cyclones in MJJ (1957, 1966, 1969, 1977, 1991, 1994, and 1999).

The years with the most extreme ENSO anomalies correspond closely to years with the most extreme cyclone counts during the MJJ season. The seven years with the lowest Niño3 temperatures 
(Niño3 $<25.6^{\circ} \mathrm{C}$ ) include two of the highest cyclone count years, 1955 and 1970. Three other years among the lowest seven Niño3 temperatures $(1954,1973$, and 1975) had five tropical cyclones in MJJ, and 1988 had four. Hence six of the seven years with the lowest Niño3 values had aboveaverage MJJ cyclone counts. The year 1964, with just two cyclones, is the exception.

To characterize warm (El Niño) years, we considered the eight years of this data record in which Niño3 exceeded $27^{\circ} \mathrm{C}$ in MJJ. Four of these years had zero, one, or two MJJ cyclones, and all but one year had below-average (three or fewer) MJJ cyclone counts, the exception being 1987 when five cyclones occurred. We will consider the exceptional years 1964 and 1987 after examining composite circulation anomalies for the seven years with the fewest ( 0 or 1$)$ and seven years with the most (6) near-coastal cyclone counts in MJJ.

Composite difference plots between these two sets of years for lower tropospheric geopotential height and SST are shown in Fig. 5. Although these composites are based on small samples, the differences between MJJ seasons with many or few cyclones illustrate some intriguing features that provide working hypotheses to account for the interannual variations in near-coastal tropical cyclone occurrence.

The $700 \mathrm{hPa}$ geopotential height difference map (Fig. 5a) shows a pronounced positive height difference centered on the coast near $30^{\circ} \mathrm{N}, 120^{\circ} \mathrm{W}$ at the location of a climatological mean trough. To the south there is a broad region of negative height difference across the tropical eastern Pacific. Hence years with many (few) near-coastal cyclones tend to have a weaker (deeper) trough off the coast near Baja California and a stronger (weaker) ridge with a greater (lesser) westward extent. The trough along the equator is stronger and deeper in years with many cyclones.
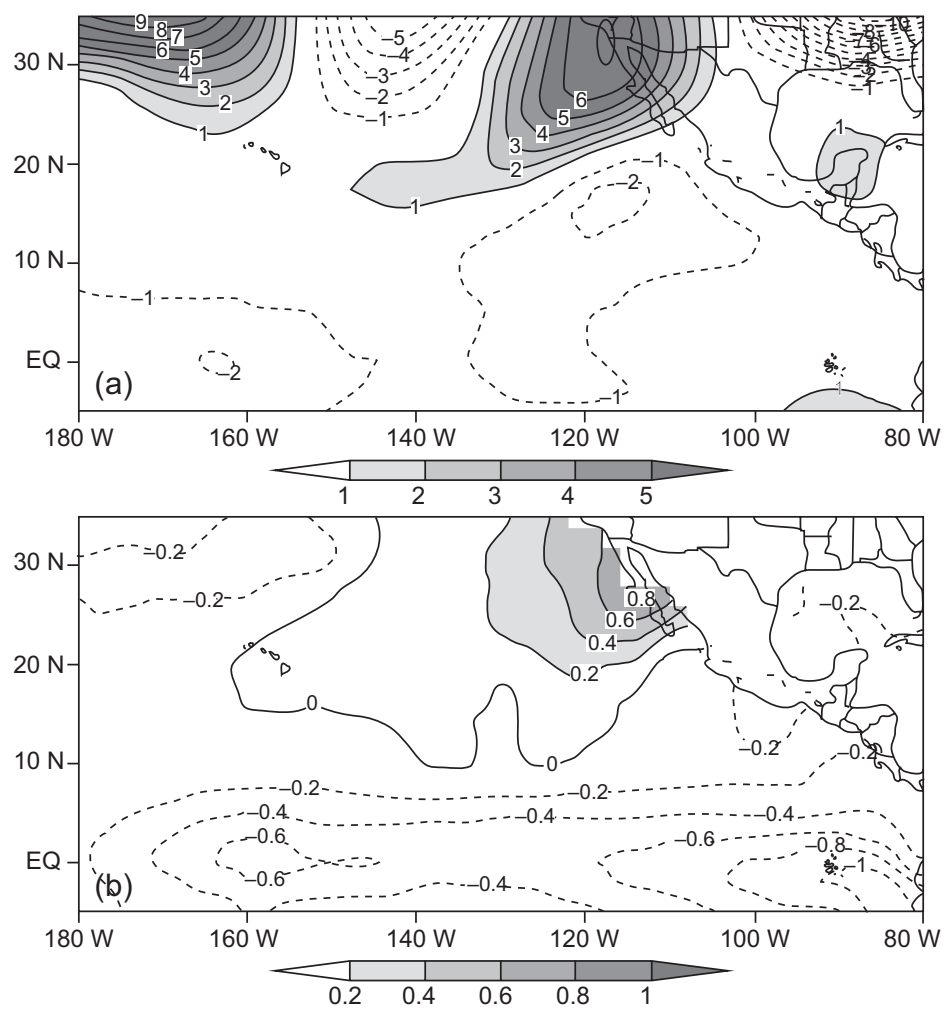

Fig. 5. Composite difference plots of (a) $700 \mathrm{hPa}$ geopotential height (contour interval $1 \mathrm{~m}$ ) and (b) SST (contour interval $0.2{ }^{\circ} \mathrm{C}$ ). Each plot shows the difference between the seven MJJ seasons with the most (6) and the seven MJJ seasons with the fewest ( 0 or 1) near-coastal cyclones. 
Anomalous westerly and southerly geostrophic flow off the west coast between $5-15^{\circ} \mathrm{N}$ and $90-110^{\circ} \mathrm{W}$ is also implied in the $700 \mathrm{hPa}$ geopotential height difference map. Such anomalous flow is also seen in near-surface and $300 \mathrm{hPa}$ fields (not shown). This difference pattern is consistent with enhanced steering flow onto the Pacific coast of southern Mexico during MJJ in years with many near-coastal cyclones. Furthermore, at longitude $120^{\circ} \mathrm{W}$ the anomalous $700 \mathrm{hPa}$ easterly flow at $20^{\circ} \mathrm{N}$ and the anomalous westerly flow at $10^{\circ} \mathrm{N}$ define enhanced cyclonic shear that can lead to enhanced near-shore tropical cyclone formation in the doldrum trough. Gray (1968) noted this to be an important condition that favored the large number of cyclones just south of Mexico.

The SST composite difference plot (Fig. 5b) confirms that an ENSO pattern is associated with extremes in MJJ near-coastal tropical cyclone counts. The difference plot is negative along the equator in the Niño3 region, showing that years with many near-coastal cyclones have colder equatorial temperatures than years with few near-coastal cyclones. The composite difference approaches $1{ }^{\circ} \mathrm{C}$ to the east of $120^{\circ} \mathrm{W}$. This is a large SST signal, considering that the seasonal cycle of ENSO typically reaches a low-amplitude phase in the May-July period used for this calculation.

However, the SST differences in Fig. 5b are small at the off-equatorial latitudes where tropical cyclones form and develop. The mean genesis location for tropical cyclones during the seven most active MJJ years in the data record was $13.1^{\circ} \mathrm{N}$ and $99.7^{\circ} \mathrm{W}$, and the corresponding location for the seven least active MJJ years was $12.3^{\circ} \mathrm{N}$ and $101.4^{\circ} \mathrm{W}$. Both of these locations are close to the $-0.2^{\circ} \mathrm{C}$ anomaly contour in Fig. 5 b, showing a minimal difference. The $26.5^{\circ} \mathrm{C}$ isotherm, considered a necessary thermodynamic condition for tropical cyclogenesis (Gray, 1979), always lies equatorward of the latitudes of cyclogenesis (SST increases poleward near the equator). Hence sufficient oceanic heat content would seem to be available for tropical cyclone formation throughout the region for both sets of years, regardless of local ENSO-related SST anomalies. We suggest that the principal effect of ENSO-related SST anomalies is to modify the off-equatorial atmospheric circulation anomalies that steer cyclones toward the North American continent after they have formed, consistent with the $700 \mathrm{hPa}$ difference map in Fig. 5a.

In the years with six near-coastal cyclones in MJJ, zonal wind shear increases west of $130^{\circ} \mathrm{W}$, while shear east of this longitude shows little change or decreases (Fig. 6a). Lower values of vertical wind shear are conducive to tropical cyclogenesis, so the region east of $130^{\circ} \mathrm{W}$, and thus closer to the coast, is more likely for tropical cyclone development in these years. The converse is true when few near-coastal cyclones occur, as vertical wind shear is more conducive farther from the coast in these years. The changes in meridional shear are minimal between the two groups of years (Fig. 6b).

\section{Summary}

Interannual fluctuations of eastern North Pacific tropical cyclones affecting the west coast of North America are modulated by the ENSO cycle and by Pacific decadal variability, particularly during the early months of the tropical cyclone season. More tropical cyclones affect the Pacific coast in May-July during La Niña years, when equatorial Pacific Ocean temperatures are anomalously cold, than during El Niño years. The difference between La Niña and El Niño years was especially pronounced during the mid-twentieth century epoch when cold equatorial ocean temperatures were enhanced in association with Pacific decadal variability.

Interannual variability of near-coastal cyclone counts is most pronounced in spring and early summer rather than at the peak of the cyclone season in late summer/early autumn. Composite 

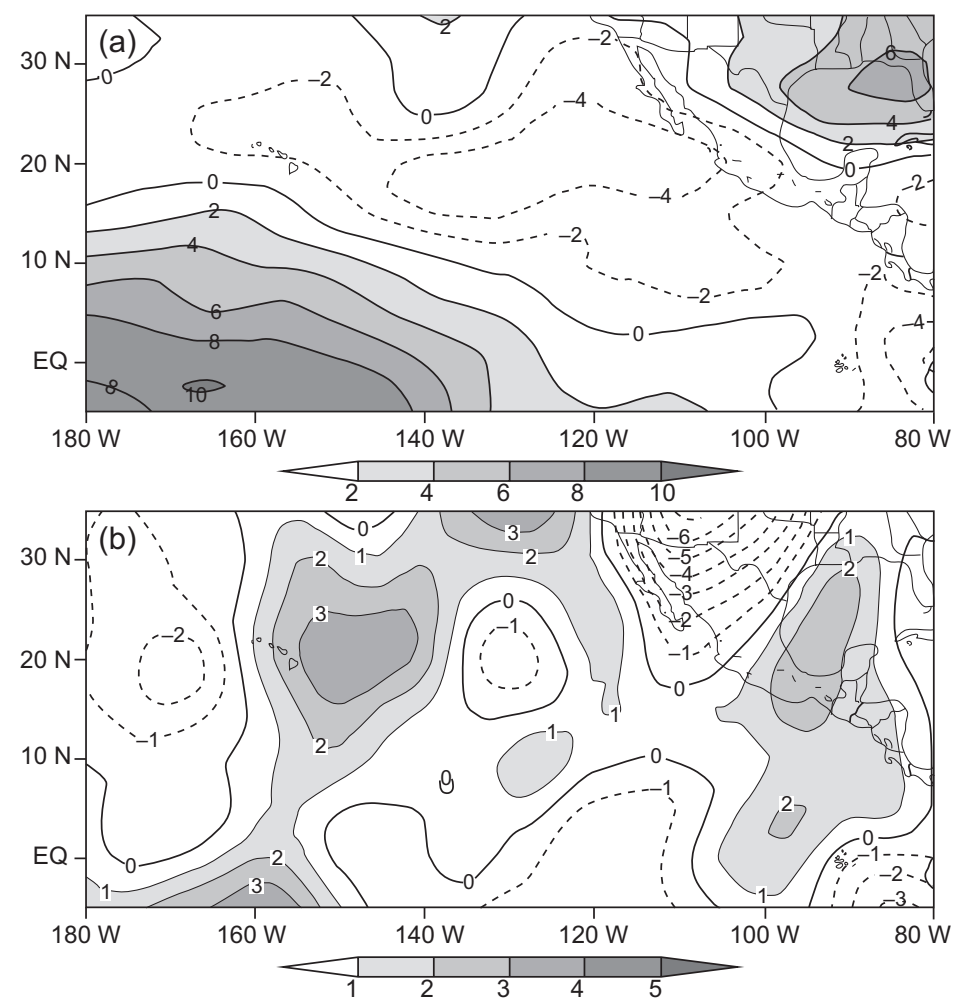

Fig. 6. Composite difference plots of (a) 200-850 hPa zonal wind shear (contour interval $2 \mathrm{kt}$ ) and (b) 200-850 hPa meridional wind shear (contour interval $1 \mathrm{kt}$ ). Each plot shows the difference between the seven MJJ seasons with the most (6) and the seven MJJ seasons with the fewest ( 0 or 1 ) near-coastal cyclones.

analysis suggests that off-equatorial circulation anomalies west of Mexico act to steer cyclones toward (away from) the coast during La Niña (El Niño) periods.

The general correspondence between enhanced near-coastal cyclone activity and La Niña would seem to be at odds with the general notion that eastern North Pacific and western Atlantic tropical cyclone activity vary inversely. It is important to emphasize the distinction between nearcoastal cyclone counts, considered here, and indices of more general eastern Pacific tropical storm activity. Gray (1984) suggested that eastern North Pacific tropical cyclones tend to track farther westward during warm years, which could help reconcile the apparent inconsistency between our results and his. Similarly, Collins and Mason (2000) showed that the positive relationship between ENSO SST anomalies and cyclone activity is restricted to the region west of $116^{\circ} \mathrm{W}$ and changes sign to negative east of $116^{\circ} \mathrm{W}$, consistent with our results.

The empirical results presented here do not definitively explain all the differences between studies of interannual variability in eastern North Pacific tropical cyclone activity. Future modeling experiments will explore the relative roles of ocean temperatures and atmospheric variability, both locally and in the western Atlantic/Caribbean basin, in modulating interannual variability of eastern North Pacific tropical cyclones. The results potentially provide a basis for empirical probabilistic seasonal prediction of the propensity for tropical cyclones to make landfall on the west coast of 
Mexico. This would require skillful predictions of Niño3 ocean surface temperature anomalies extending late into the spring season, beyond the typical peak of the ENSO cycle in boreal winter.

\section{Acknowledgments}

This research was supported by a grant from the NOAA Climate Program Office (grant no. NA030AR4310085) under the auspices of the US CLIVAR program and the NOAA Climate Prediction Program for the Americas (CPPA). Critical comments from two anonymous reviewers strengthened the manuscript.

\section{References}

Caso M., C. González-Abraham and E. Ezcurra, 2007. Divergent ecological effects of oceanographic anomalies on terrestrial ecosystems of the Mexican Pacific coast. P. Natl. Acad. Sci. USA 104, 10530-10535.

Castro C. L., T. B. McKee and R. A. Pielke, 2001. The relationship of the North American monsoon to tropical and North Pacific sea surface temperatures as revealed by observational analyses. J. Climate 14, 4449-4473.

Collins J. M. and I. M. Mason, 2000. Local environmental conditions related to seasonal tropical cyclone activity in the northeast Pacific basin. Geophys. Res. Lett. 27, 3881-3884.

Davis M. A. S., G. M. Brown and P. Leftwich, 1984. A tropical cyclone data tape for the eastern and central North Pacific basins, 1949-1983. Contents, limitations, and uses. NOAA Tech Memo NWS NHC-25. Miami: NHC, 17 pp.

Englehart P. J. and A. V. Douglas, 2001. The role of eastern North Pacific tropical storms in the rainfall climatology of western Mexico. Int. J. Climatol. 21, 1357-1370.

Frank W. M. and G. S. Young, 2007. The interannual variability of tropical cyclones. Mon. Wea. Rev. 135, 3587-3598.

Gershunov A. and T. P. Barnett, 1998. Interdecadal modulation of ENSO teleconnections. Bull. Amer. Meteor. Soc. 79, 2715-2725.

Graham N. E., 1994. Decadal-scale climate in the tropical and north Pacific during the 1970s and 1980s: Observations and model results. Climate Dyn. 10, 135-162.

Gray W. M., 1968. Global view of the origin of tropical disturbances and storms. Mon. Wea. Rev. 96, 669-700.

Gray W. M., 1979. Hurricanes: Their formation, structure and likely role in the tropical circulation. In: Meteorology over the tropical oceans (D. B. Shaw, Ed.). Reading, U.K.: Royal Meteorological Society, 155-218.

Gray W. M., 1984. Atlantic seasonal hurricane frequency. Part I: El Niño and 30 mb quasi-biennial oscillation influences. Mon. Wea. Rev. 112, 1649-1668.

Gutzler D. S. and J. W. Preston, 1997. Evidence for a relationship between spring snow cover and summer rainfall in New Mexico. Geophys. Res. Lett. 24, 2207-2210.

Gutzler D. S., 2000. Covariability of spring snowpack and summer rainfall across the American Southwest. J. Climate 13, 4018-4027.

Gutzler D. S., D. M. Kann and C. Thornbrugh, 2002. Modulation of ENSO-based long-lead outlooks of Southwest U.S. winter precipitation by the Pacific Decadal Oscillation. Weather Forecast. 17, 1163-1172. 
Gutzler D. S., 2004. An index of interannual precipitation variability in the core of the North American monsoon region. J. Climate 17, 4473-4480.

Higgins R. W., Y. Chen and A. Douglas, 1999. Interannual variability of the North American warm season precipitation regime. J. Climate 12, 653-679.

$\mathrm{Hu}$ Q. and S. Feng, 2001. Variations of teleconnection of ENSO and interannual variations in summer rainfall in the central United States. J. Climate 14, 2469-2480.

Irwin R. P. and R. E. Davis, 1999. The relationship between the Southern Oscillation Index and tropical cyclone tracks in the eastern North Pacific. Geophys. Res. Lett. 26, 2251-2254.

Jáuregui E., 2003. Climatology of landfalling hurricanes and tropical storms in Mexico. Atmósfera 16, 193-204.

Kalnay E., M. Kanamitsu, R. Kistler, W. Collins, D. Deaven, L Gandin, M. Iredell, S. Sana, G. White, J. Woollen, Y. Zhu, M. Chelliah, W. Ebisuzaki, W. Higgins, J. Janowiak, K. C. Mo, C. Ropelewski, J. Wang, A. Leetmaa, R. Reynolds, R. Jenne and D. Joseph, 1996. The NCEP/ NCAR 40-year reanalysis project. Bull. Amer. Meteor. Soc. 77, 437-471.

Kim H. M., P. J. Webster and J. A. Curry, 2011. Modulation of North Pacific tropical cyclone activity by three phases of ENSO. J. Climate 24, 1839-1849.

Klotzbach and W. M. Gray, 2004. Updated 6-11 month prediction of Atlantic basin seasonal hurricane activity. Weather Forecast. 19, 917-934.

Klotzbach P. J., 2008. Refinements to Atlantic basin seasonal hurricane prediction from 1 December. J. Geophys. Res. 113, D17109, doi:10.1029/2008JD010047.

Lander M. A. and C. P. Guard, 1998. A look at global tropical cyclone activity during 1995: Contrasting high Atlantic activity with low activity in other basins. Mon. Wea. Rev. 126, 11631173.

Larson J., Y. Zhou and R. W. Higgins, 2005. Characteristics of landfalling tropical cyclones in the United States and Mexico: Climatology and interannual variability. J. Climate 18, 1247-1262.

Lewis M. D., 2003. A comprehensive revision of eastern North Pacific tropical cyclone tracks, 1921-1966. Master in Science thesis, Dept. of Atmospheric Sciences, Creighton University, 81 pp. plus appendices.

Lo F. and M. P. Clark, 2002. Relationships between spring snow mass and summer precipitation in the southwestern USA associated with the North American monsoon system. J. Climate 15, 1378-1385.

Magaña V. O., J. L. Vázquez, J. L. Pérez and J. B. Pérez, 2003. Impact of El Niño on precipitation in Mexico. Geofis. Int. 42, 313-330.

Magaña V. O. (ed.), 2004. Los Impactos de El Niño en México. Mexico: Conacyt/UNAM, 228 pp.

Mantua N. J., S. R. Hare, Y. Zhang, J. M. Wallace and R. C. Francis, 1997. A Pacific interdecadal climate oscillation with impacts on salmon production. Bull. Amer. Meteor. Soc. 78, 1069-1079.

McCabe G. J. and M. D. Dettinger, 1999. Decadal variations in the strength of ENSO teleconnections with precipitation in the western United States. Int. J. Climatol. 19, 1399-1410.

Ralph T. U. and W. A. Gough, 2009. The influence of sea surface temperatures on eastern North Pacific tropical cyclone activity. Theor. Appl. Climatol. 95, 257-264.

Reyes S. and A. Mejía-Trejo, 1991. Tropical perturbations in the eastern Pacific and the precipitation field over north-western Mexico in relation to the ENSO phenomenon. Int. J. Climatol. 11, 515-528.

Serra S., 1971. Hurricanes and tropical storms of the west coast of Mexico. Mon. Wea. Rev. 99, 302-308. 
Whitney L. D. and J. S. Hobgood, 1997. The relationship between sea surface temperature and maximum intensities of tropical cyclones in the northeastern Pacific Ocean. J. Climate 10, 2921-2930.

Wu P. and P.S. Chu, 2007. Characteristics of tropical cyclone activity over the eastern North Pacific: The extremely active 1992 and the inactive 1977. Tellus 59A, 444-454.

Zhao X. and P. S. Chu, 2006. Bayesian multiple changepoint analysis of hurricane activity in the eastern North Pacific: A Markov chain Monte Carlo approach. J. Climate 19, 564-578. 